\title{
Effect of Selenoamides compounds on the survival and differentiation of mesenchymal dental pulp stem cells.
}

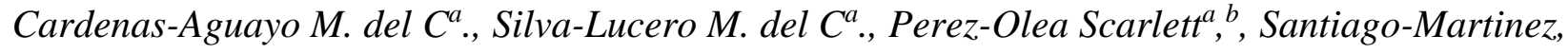 \\ Arleth, $A^{a},{ }^{b}$. \\ ${ }^{a}$ Laboratory of Cellular Reprogramming and Chronic-Degenerative Diseases, School of Medicine, \\ National Autonomous University of Mexico (UNAM). \\ ${ }^{b}$ Higher School of Natural Sciences, Autonomous University of Guerrero (UAGro).
}

\section{Graphical Abstract}

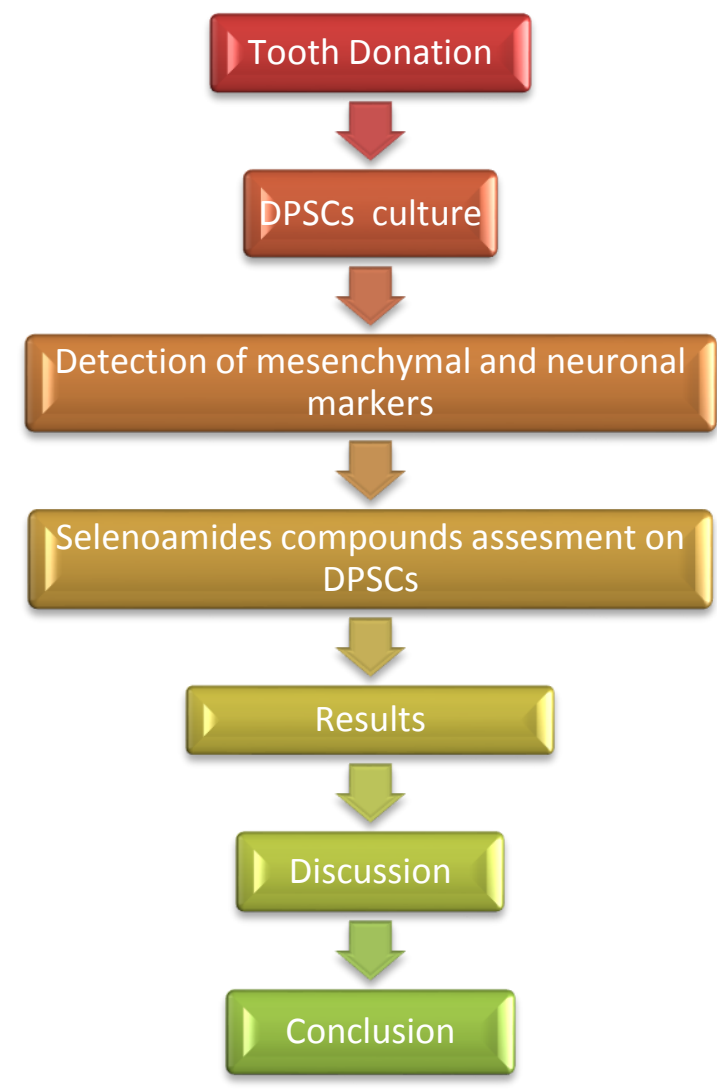

Abstract.

Alzheimer's disease is the most common cause of dementia in elderly people. Currently there are near to 50 million cases of Dementia worldwide, among them 60-70 \% correspond to Alzheimer's disease. Unfortunately, the only diagnosis available is postmortem and there is no treatment or cure. However, studies by several authors have proposed Selenoamides as neuroprotective compounds, since they promote survival pathways on stress conditions.

We cultured Dental Pulp Stem Cells (DPSCs) in DMEM/F12 with $10 \%$ fetal bovine serum, medium was changed every third day until they reached a confluence of approximately $70-80 \%$, then we treated these cells with the Selenoamides compounds. Cells were fixed with paraformaldehyde (PFH) $\quad 4 \%$ for immunofluorescence; and protein was extracted for Western blot to detect mesenchymal, stem cell and neuronal markers, such as: CD73, CD13, CD105; and SOX2, OCT4, and Nanog, and b-IIITubulin, respectively. Neuroprotection by Selenoamides compounds was measured with MTT viability assay. We found that one among seven Selenoamide compounds, showed 
significant effects on DPSCs survival, at relatively low concentration. Our results support the potential use of selenoamides as new therapeutics for Alzheimer's disease.

\section{Introduction}

This research aims to differentiate mesenchymal cells from the dental pulp towards the neuronal lineage as a possible therapeutic tool for Alzheimer's disease that is the main cause of dementia in older adults and is characterized by neurodegeneration affecting memory and cognitive function. Currently there are different therapies based on trying to improve cognitive ability, but it has little impact on the prevention and delay of the neurodegenerative process, so it is important to validate new drugs that may be more efficient in the control of neurodegeneration.

Today, regenerative medicine has implemented mesenchymal stem cell therapies to seek a better alternative in organ transplantation, in the treatment of diabetes, atherosclerosis, and neurodegenerative diseases. (Pillai et al., 2014).

Materials and Methods (optional)

\section{References}


CARDENAS-AGUAYO MDEL, C., GOMEZ-VIRGILIO, L., DEROSA, S. \& MERAZ-RIOS, M. A. 2014. The role of tau oligomers in the onset of Alzheimer's disease neuropathology. ACS Chem Neurosci, 5, 1178-91.

LÓPEZ-CORTÉS, J. G., ALFARO, M. C. O., ALVAREZ, C., CRUZ, L. F. C. D. L., TOSCANO, R. A. \& RUDLER, H. 2005. Improved approaches and structures of new ferrocenyl carbene complexes of chromium, tungsten, and molybdenum. Journal of Organometallic Chemistry, 690, 2237.

PILLAI, R., UYEHARA-LOCK, J. H. \& BELLINGER, F. P. 2014. Selenium and selenoprotein function in brain disorders. IUBMB Life, 66, 229-39.

PITTENGER, M. F., MACKAY, A. M., BECK, S. C., JAISWAL, R. K., DOUGLAS, R., MOSCA, J. D., MOORMAN, M. A., SIMONETTI, D. W., CRAIG, S. \& MARSHAK, D. R. 1999. Multilineage potential of adult human mesenchymal stem cells. Science, 284, 143-7.

YANG, S., LEONG, K. F., DU, Z. \& CHUA, C. K. 2001. The design of scaffolds for use in tissue engineering. Part I. Traditional factors. Tissue Eng, 7, 679-89 